\title{
Methods to Improve the Nutrition of Brook Trout (Salvelinus fontinalis $M$.) by Using Foder Additives (Bio-Mos, Nupro, Sel-plex)
}

\author{
Aurel ŞARA*1), Mihai BENŢEA ${ }^{1)}$, Alina $\mathrm{ANI}^{2)}$, Marin BREJE ${ }^{1)}$, Călina CREŢA ${ }^{3)}$ \\ $\left.{ }^{1}\right)$ University of Agricultural Sciences and Veterinary Medicine, Faculty of Animal Science and \\ Biotechnologies, 3-5 Mănăștur Street, 400372 Cluj-Napoca, Romania \\ ${ }^{2)}$ Alltech Romania \\ ${ }^{3)}$ National Institute of Public Health, Romania \\ *Corresponding author, email: asara950@yahoo.com \\ Bulletin UASVM Animal Science and Biotechnologies 71(2) / 2014, \\ Print ISSN 1843-5262; Electronic ISSN 1843-536X \\ DOI:10.15835/buasvmcn-asb:10447
}

\begin{abstract}
The research aimed to determine the effects of some fodder additives (Bio-Mos, Nupro and Sel-plex) on growth and consumption indices, meat quality and survival rate in brook trout. The research has been carried out on a number of 1000 fishes, randomly distributed in 4 groups (250 fish/group): a control group, group 1E (BioMos $0.2 \%$ ), group 2E (NuPro 2\%) and group 3E (Sel-plex 0.03\%); the experimental period was 250 days. During the experiment the following parameters were recorded and analyzed: body mass evolution, weight gain, specific growth rate, feed conversion ratio (FCR), meat quality and survival rate. The best results were recorded in group 1E (Bio-Mos 0.2\%), with a body weight of $248.45 \mathrm{~g}$, a weight gain of $228.45 \mathrm{~g}$ and a FCR of $1.18 \mathrm{~kg}$ fodder $/ \mathrm{kg}$ weight gain. The high values of meat Selenium content show the cumulative effect of organic Selenium in the fish meat; as a result, this meat can be considered a functional food. The highest survival rate was recorded in group 3E (95.60\%), receiving dietary Selenium supplementation.
\end{abstract}

Keywords: fodder additives, brook trout, growth and consumption indices, meat quality, survival rate

\section{INTRODUCTION}

Prebiotics and organic minerals are of great interest in fish nutrition.

The positive effects of Bio-Mos prebiotic on salmonids have being reported by Staykov et al. (2005) and Dimitroglou et al. (2005). The use of Bio-Mos prebiotic leads to the improvement of the growth rhythm and bio-mass accumulation, to a better feed conversion and the subsequent reduction of FCR, and to an increased survival rate (Barbu, 2010; Hossu et al. 2005; Torrecillas, 2011). A new tendency in aquaculture is to replace the sources of animal proteins in feeds; thus the feed manufacturers are searching for alternative protein sources that are more digestible and palatable. Such an alternative is represented by yeasts extracts, such as the NuPro protein extract, which has favorable effects on production and reproduction performances of fishes and also on their health status (Burrells et al. 2001; GonzalesVecino, 2002). The organic Selenium used in fish nutrition positively influences the growth rhythm, feed conversion, meat quality, maintains a good health status and reduces mortality rates (Yamb et al. 2006)

The aim of the research was to highlight the effects of these additives (Bio-Mos, NuPro and organic Selenium -Sel-plex) on the growth and consumption indices, meat quality and survival rates in brook trout.

\section{MATERIALS AND METHODS}

The experiment was carried out between August 21, 2012 and April 28, 2013 (over a period of 250 days) in a trout farm situated in the Upper Tranis, Cluj county, on 1000 brook trout, divided in 
4 groups, as follows: control group, group $1 \mathrm{E}-$ that received Bio-Mos supplemented fodders $(0.2 \%)$, group 2E -that received NuPro supplemented fodders $(2 \%)$ and group $3 \mathrm{E}$ that received organic Selenium enriched fodders (Sel-plex $0.03 \%$ ). The fishes from the experimental groups were reared in the same environmental conditions (water quality, stocking density, feeding timetable and fodder quality). The values for the physical and chemical parameters of water are within the normal limits for the species, cited by the literature. The feed used was a granulated fodder (Bărbieru, 2012) acquired from Aqua-Garant Company (Austria), having the following nutritional characteristics: crude protein $42 \%$, crude fat $16 \%$, crude fiber $3.5 \%$, crude ash $2.5 \%$, calcium $1 \%$, phosphorous $1 \%$, sodium $0.20 \%$. Throughout the experimental period the following parameters were recorded: body mass evolution, weight gain, specific growth rate, FCR, meat quality and survival rate.

The determination of meat quality was based on the chemical composition of meat (water, dry matter, crude protein, and crude fat) and was carried out in the Laboratory of Feed Quality Control from UASVM Cluj Napoca. The Selenium content of meat was determined using the atomic absorption spectrophotometer method and was carried out at the Institute of Hygiene Cluj-Napoca.

The experimental data were statistically analyzed by means of the Student test, using the GraphPad Instat software, v3.10.

\section{RESULTS AND DISCUSSION}

The mean values and the variability of body mass in the brook trout at the beginning and at the end of the experimental period are shown in Table 1. By analyzing the recorded results regarding the body weight of the trout from the 4 experimental groups, at the end of the experimental period, a $11.59 \%$ improvement can be seen in group $1 \mathrm{E}$ (Bio-Mos 0.2\%) compared to the control group, results comparable to those of Staykov et al. (2005). The other experimental groups showed more tight values, as follows: $235.35 \mathrm{~g}$ in group $2 \mathrm{E}$ (NuPro 2\%), $223.46 \mathrm{~g}$ in group $3 \mathrm{E}$ (SelPlex 0.03\%) and $214.35 \mathrm{~g}$ in the control group. All the groups presented a medium variability $(10 \%<\mathrm{V} \%<20 \%)$ regarding the body weight.

At the end of the experimental period distinctly significant differences were recorded between group $1 \mathrm{E}$ (Bio-Mos 0,2\%) and the control group regarding the body weight, these differences certifying the positive influence of mannanoligosaccharides (Bio-Mos) on growth rhythm and bio-mass accumulation in brook trout. For a real estimation of the growth dynamics of the trout from the 4 experimental groups, the weight gain and the specific growth rate were determined, these being the main indicators of the bio-mass accumulation rhythm.

The effects of these additives (Bio-Mos, NuPro, Sel-plex) on the growth and consumption indices recorded in the 4 experimental groups, are shown in Table 2. The main growth indices recorded throughout the experimental period show a favorable influence of the bio-additives administered(Bio-Mos 0.2\%,NuPro 2\% and Sel-plex $0.03 \%$ ) on the weight gain. A $17.54 \%$ improvement was recorded in group 1E (Bio-Mos) compared to the control group (228.45 g in group 1E vs 194.35 $\mathrm{g}$ in the control group) and the improvement of the weight gain for group $2 \mathrm{E}$ and $3 \mathrm{E}$ by $10.80 \%$ and $4.68 \%$, compared to the control group. The highest value of the growth rate was recorded in group $1 \mathrm{E}$ $(0.91 \mathrm{~g} /$ day), $18.18 \%$ higher than the one recorded in the control group. The other two experimental groups had superior growth rates, compared to the

Tab.1. Body weight of brook trout at the beginning and at the end of the experimental period

\begin{tabular}{ccccc}
\hline \multirow{2}{*}{ Group } & $\mathrm{n}$ & $\begin{array}{c}\text { Initial body weight }(\mathrm{g}) \\
\mathrm{X} \pm \mathrm{Sx}\end{array}$ & $\begin{array}{c}\text { Final body weight }(\mathrm{g}) \\
\mathrm{X} \pm \mathrm{Sx}\end{array}$ & $\mathrm{V} \%$ \\
\hline Control & 30 & 20 & $214.35 \pm 5.90$ & 12.80 \\
\hline 1E (Bio-Mos) & 30 & 20 & $248.45 \pm 7.97^{* *}$ & 14.54 \\
\hline 2E (NuPro) & 30 & 20 & $235.35 \pm 6.21^{*}$ & 12.38 \\
\hline 3 E (SelPlex) & 30 & 20 & $223.46 \pm 7.14$ & 15.18 \\
\hline
\end{tabular}

**- $\mathrm{p}<0.01$ - distinctly significant differences

*- $\mathrm{p}<0.05$ - significant differences 
Tab. 2. The main growth and consumption indices, recorded at the end of the experimental period, in brook trout

\begin{tabular}{cccccc}
\hline Issue & U.M. & $\begin{array}{c}\text { Control } \\
\text { group }\end{array}$ & $\begin{array}{c}\text { Group 1E } \\
\text { (Bio-Mos 0.2\%) }\end{array}$ & $\begin{array}{c}\text { Group 2E } \\
\text { (NuPro 2\%) }\end{array}$ & $\begin{array}{c}\text { Group 3E } \\
\text { (Sel-plex 0.03\%) }\end{array}$ \\
\hline \multirow{2}{*}{ Weight gain } & $\mathrm{g}$ & 194.35 & 228.45 & 215.35 & 203.46 \\
\cline { 2 - 6 } & $\%$ & 100.00 & 117.54 & 110.80 & 104.68 \\
\hline $\begin{array}{c}\text { Specific growth } \\
\text { rate }\end{array}$ & $\mathrm{g}$ /day & 0.77 & 0.91 & 0.86 & 0.81 \\
\hline $\begin{array}{c}\text { FCR Feed } \\
\text { conversion rate }\end{array}$ & $\begin{array}{c}\mathrm{kg} \text { feed/ kg } \\
\text { body weight }\end{array}$ & $1.27: 1$ & $1.18: 1$ & $1.35: 1$ & $1.29: 1$ \\
\hline
\end{tabular}

Tab. 3. The chemical composition of meat in brook trout

\begin{tabular}{lccccc}
\hline Issue & $\mathrm{n}$ & S.U. \% & Water content $\%$ & $\mathrm{CP} \%$ & $\mathrm{CF} \%$ \\
\hline Control group & 10 & $24.74 \pm 0.40$ & $75.25 \pm 0.4$ & $17.59 \pm 0.33$ & $6.30 \pm 0.36$ \\
\hline Group 1E (Bio-Mos 0.2\%) & 10 & $26.05 \pm 0.44$ & $73.94 \pm 0.44$ & $18.04 \pm 0.37$ & $6.80 \pm 0.15$ \\
\hline Group 2E (NuPro 2\%) & 10 & $25.92 \pm 0.39$ & $74.07 \pm 0.39$ & $17.57 \pm 0.28$ & $6.72 \pm 0.29$ \\
\hline Group 3E (Sel-plex 0.03\%) & 10 & $25.76 \pm 0.55$ & $74.22 \pm 0.56$ & $18.09 \pm 0.40$ & $6.40 \pm 0.47$ \\
\hline Reference values & & 22.97 & 80.00 & $14.00-18.90$ & $2.70-10.60$ \\
\hline \multirow{2}{*}{ Source } & & Bud and & Stephen & Savic N & \multirow{2}{*}{ www.fao.org } \\
\hline
\end{tabular}

Tab. 4. The meat Selenium content in brook trout $(\mu \mathrm{g} / \mathrm{kg})$

\begin{tabular}{lcc}
\hline Issue & Control group & Group 3E (Sel-plex 0,03\% \\
\hline $\mathrm{n}$ & 10 & 10 \\
\hline $\mathrm{Se}(\mu \mathrm{g} / \mathrm{kg})$ & $63.83 \pm 1.21$ & $224.673 \pm 4.48^{* * *}$ \\
$\mathrm{X} \pm \mathrm{Sx}$ & & \\
\hline
\end{tabular}

***- $\mathrm{p}<0.001$ very significant differences

Tab. 5. Survival rates recorded at the end of the experimental period, in brook trout

\begin{tabular}{lcccc}
\hline Issue & Control group & $\begin{array}{c}\text { Group 1 E } \\
\text { (Bio-Mos 0,2\%) }\end{array}$ & $\begin{array}{c}\text { Group 2E } \\
\text { (NuPro 2\%) }\end{array}$ & $\begin{array}{c}\text { Group 3E } \\
\text { (Sel-plex 0,03\%) }\end{array}$ \\
\hline Initial number & 250 & 250 & 250 & 250 \\
\hline Final number & 198 & 216 & 206 & 239 \\
\hline Survival (\%) & 79.20 & 86.40 & 82.40 & 95.60 \\
\hline Losses (\%) & 20.80 & 13.60 & 17.60 & 4.40 \\
\hline
\end{tabular}

control group $(0.86 \mathrm{~g} /$ day in group $2 \mathrm{E}$, and $0.81 \mathrm{~g} /$ day in group 3E).

The recorded feed conversion ratio values (FCR) were higher in group 2E (NuPro) 1.35:1 compared to group 1 (Bio-Mos)-1.18:1 and 1.27:1 and 1.29:1 in group 3E and in the control group respectively. The addition of $0.2 \%$ Bio-Mos in the feeds administered to group $1 \mathrm{E}$ determined a
7.09\% lower FCR. This drop was also confirmed on other fish species that received 0.2\% Bio-Mos in their feeds (Staykov et al. 2005; Culjak et al. 2006; Bogut et al. 2006; Torrecillas Silvia, 2011).

Besides the growth and consumption indices, the effects of the additives on meat quality were also determined. The results recorded after the chemical analysis of meat are presented in Table 3. 
The addition of the three additives did not influence the chemical composition of meat, the differences recorded being non-significant. The use of additives led to a minor increase in protein content in the experimental groups 1E (Bio-Mos $0.2 \%$ ) and 3E (Sel-plex 0.03\%) $-18.04 \%$ PB and $18.09 \%$ PB respectively and also a decrease in meat water content in all the experimental groups, compared to the control group. The meat Selenium content was significantly higher in group 3E (Selplex, $0.03 \%$ ) who's feeds were supplemented with organic Selenium (Tab. 4).

The recorded meat selenium content showed a very significant increase as a result of Selenium supplementation (as Sel-Plex); this could be the first step in the creation of a functional feed.

A very important parameter, one that is closely monitored in a trout farm, is the survival rate of fishes. The survival rates of the fishes in the four experimental groups were recorded throughout the experimental period and are presented in Table 5.

The use of additives led to the improvement of the survival rates in all the experimental groups -by $7.2 \%$ for group $1 \mathrm{E}$ (Bio-Mos $0.2 \%$ ), by $3.2 \%$ for group $2 \mathrm{E}$ (NuPro $2 \%$ ) and by $16.4 \%$ for group $3 \mathrm{E}$ (Sel-plex $0.03 \%$ ), results comparable to those reported by Yambo et al., 2006).

\section{CONCLUSION}

The best result regarding the body mass evolution were recorded in group $1 \mathrm{E}$ (Bio-Mos $0.2 \%$ ), followed by groups 2E (NuPro 2\%) and 3E (Sel-plex $0.03 \%$ ). The weight gain was inproved by $17.54 \%$ for group 1E (Bio-Mos 0.2\%) and by $10.80 \%$ in group 2E (NuPro 2\%) compared to the control group. The most efficient FCR was recorded in group 1E (Bio-Mos 0.2\%) (1.18:1). Regarding the meat quality, a minor increase in protein content was recorded in groups $1 \mathrm{E}$ (Bio-Mos) and $3 \mathrm{E}$ (Sel-plex). The highest selenium content of meat was recorded in group 3E that received Selenium supplemented fodders. The use of the additives led to the improvement of the survival rate. The highest survival rate was recorded in group 3E (Sel-Plex) (95.6\%), 16.4\% higher than the control group.

Based on the recorded results and based on the formulated conclusions, we recommend the use of Bio-Mos prebiotic, in a dose of $0.2 \%$, organic Selenium, in a dose of $0.03 \%$ and NuPro protein extract, in a dose of $2 \%$, in salmonids, separately, based on the desired productive indices.

\section{REFERENCES}

1. Barbu A (2010). Utilizarea aditivilor furajeri în alimentaţia unor specii de pești. Teză de doctorat USAMV Cluj-Napoca.

2. Bărbieru VA (2012). Instalatii, utilaje si masini pentru piscicultura, Editura Risoprint Cluj-Napoca, ISBN 978973-53-0781-3.

3. Bogut I, Milakovic Z, Pavlicevic J, Petrovic D (2006). Effect of Bio-Mos on performance and health of European Catfish. In: Nutrition and biotechnology in the feed and food industries: Alltech's $22^{\text {nd }}$ annual symposium (suppl. 1- abstracts of posters presented), Lexington, KY, USA.

4. Bud I, Mireşan Vioara (2008). Contributions concerning the quality indices' appreciation in main aquatic organisms, which fall under human consumption. AACL Bioflux 1:73-83. Printed version: ISSN 1844-8143 online version: ISSN 1844-9166.

5. Burrells C, Williams PD, Southgate PJ, Wadsworth SL (2001). Dietary nucleotides: a novel supplement in fish feeds: 2 . Effects on vaccination, salt water transfer, growth rates and physiology of atlantic salmon (Salmo salar L.) Aquaculture 199: 171-184.

6. Culjak V, Bogut I, Has-Schon, Milakovic Z, Canecki $\mathrm{K}$ (2006). Effect of Bio-Mos on performance and health of juvenile carp. In: Nutrition and biotechnology in the feed and food industries: Alltech's $22^{\text {nd }}$ annual symposium (suppl. 1- abstracts of posters presented), Lexington, KY, USA.

7. Dimitroglou A, Davies S, Divanach P, Chatzifotis S (2005). The role of mannan oligosaccharide in gut development of white sea bream, Diplodus sargus. Alltech's 21st Annual Nutritional Biotechnology in the Feed \& Food Industries Symposium, Lexington, KY.

8. Gonzales-Vecino JL (2002). Breakthrough in broodstock nutrition. Seafish Aquaculture: Marine Finfish News. No. 1, Summer, 4.

9. Hossu B, Salnur S, Gultepe N (2005). The effects of yeast derivates (Bio-Mos) on growth of Gilthead sea bream, Sparus aurata. In: Nutritional Biotechnology in the Feed \&Food Industries. Proceedings of Alltech's 21st Annual Symposium (Suppl.1)(Abstracts of posters presented). Lexington, KY, 23-25.

10. Savic N, Mikavica D, Grujic R, Bojanic V, Vucic G, Mandic S, Urica R (2008). Chemical composition of meat of rainbow trout (Oncorhynchus mykiss W.) from Gornji Ribnik fishpond. Institute of Meat Hygiene and Technology. http://www.cababstractplus.org

11. Staykov Y, Denev S, Spring P (2005). The effects of mannan oligosaccharide (Bio-Mos) on the growth rate and immune function of rainbow trout (Salmo gairdneri irideus G.) grown in raceways. Lessons from the past to optimise the future, Ed. By Howell and R. Flos. European Aquaculture Society, Special Publication n.35, June 429430.

12. Stephen JG, Moccia RD, Bureau DP (2005). Growth and whole body composition of lake trout (Salvelinus 
namaycush), brook trout (Salvelinus fontinalis) and their hybrid, F1 splake (Salvelinus namaycush $x$ Salvelinus fontinalis) from first-feeding to 16 weeks post firstfeeding.. Aquaculture, Vol. 249, Issues 1-4, 195-204.

13. Torrecillas Silvia (2011). Effects of dietary mannan oligosaccharides (MOS) on European sea bass (Dicentrarchus labrax) juvenile culture. PhD Thesis 2011.
14. Yambo W, Jianzhong H, Weifen L, Zirong X (2006). Effect of different selenium source on groeth performances, glutathione peroxidase activites, muscules composition and selenium conception of alloghynogenetic crucian carp (Carassus auratus gibelio), Feed Science Institute of Zhejiang University, Hangzhou, China.

15. www.fao.org 